\title{
THE TERROIR OF WHISKEY
}


ARTS AND TRADITIONS OF THE TABLE:

PERSPECTIVES ON CULINARY HISTORY

Albert Sonnenfeld, Series Editor

For a complete list of titles, see page 353 . 


\section{ROB ARNOLD}

\section{THE TERROIR OF WHISKEY}

A Distiller's Journey Into the Flavor of Place 


$$
\begin{aligned}
& \text { Columbia University Press } \\
& \text { Publishers Since I893 } \\
& \text { New York Chichester, West Sussex } \\
& \text { cup.columbia.edu } \\
& \text { Copyright (C) 202I Rob Arnold } \\
& \text { All rights reserved }
\end{aligned}
$$

Library of Congress Cataloging-in-Publication Data

Names: Arnold, Robert, 1987- author.

Title: The terroir of whiskey : a distiller's journey into the flavor of place /

Rob Arnold.

Description: New York : Columbia University Press, [202I] | Series:

Arts and traditions of the table: perspectives on culinary history |

Includes bibliographical references and index.

Identifiers: LCCN 2020026158 (print) | LCCN 2020026159 (ebook) |

ISBN 978023II94587 (hardback) | ISBN 9780231550895 (ebook)

Subjects: LCSH: Whiskey—United States. | Distilleries—United States. |

Distillers-United States.

Classification: LCC TP605 .A767 2020 (print) | LCC TP605 (ebook) |

DDC 663/.50092-dc23

$\mathrm{LC}$ record available at https://1ccn.loc.gov/2020026158

LC ebook record available at https://lccn.loc.gov/2020026159

Columbia University Press books are printed on permanent and durable acid-free paper.

Printed in the United States of America

Cover design: Noah Arlow

Cover image: Kai Tilgner / Getty Images 
What we know is a drop, what we don't know is an ocean.

-Isaac Newton 
